Abstracta Iranica Abstracta Iranica

Revue bibliographique pour le domaine irano-aryen

Volume 23 | 2002

Comptes rendus des publications de $\mathbf{2 0 0 0}$

\title{
« Le mystère des monnaies iraniennes contremarquées de l'aigle russe ». La vie numismatique, 47, 4 (1997), pp. 127-132.
}

\section{Rudi Matthee}

\section{OpenEdition}

1 Journals

Édition électronique

URL : http://journals.openedition.org/abstractairanica/35391

DOI : 10.4000/abstractairanica.35391

ISSN : 1961-960X

Éditeur :

CNRS (UMR 7528 Mondes iraniens et indiens), Éditions de l'IFRI

Édition imprimée

Date de publication : 15 mai 2002

ISSN : 0240-8910

Référence électronique

Rudi Matthee, « « Le mystère des monnaies iraniennes contremarquées de l'aigle russe ». La vie numismatique, 47, 4 (1997), pp. 127-132. », Abstracta Iranica [En ligne], Volume 23 | 2002, document 141, mis en ligne le 08 février 2010, consulté le 25 septembre 2020. URL : http:// journals.openedition.org/abstractairanica/35391 ; DOI : https://doi.org/10.4000/abstractairanica. 35391

Ce document a été généré automatiquement le 25 septembre 2020.

Tous droits réservés 
« Le mystère des monnaies iraniennes contremarquées de l'aigle russe ». La vie numismatique, 47, 4 (1997), pp. 127-132.

\section{Rudi Matthee}

L'A. analyse le phénomène des monnaies persanes qui ont été contremarquées de gravures russes - l'aigle bicéphale - pendant l'occupation russe de l'Iran septentrional entre 1719 et 1732. Markov et autres numismatistes russes ont attribué cette pratique à une mesure de réorganisation du système local entreprise par les autorités russes afin de pallier des retards dans l'arrivée des devises russes (monnaies persanes refondues et refrappées en émissions russes) destinées au paiement des troupes. Plusieurs énigmes s'attachent toujours aux rares exemplaires de ce type qui ont été recensés. Ainsi par exemple, l'usure extrême de la gravure originale par rapport à la contremarque, alors que la frappe est toujours quasi contemporaine des contremarques. Sur quelques monnaies le problème est encore compliqué davantage par l'existence d'une seconde contremarque en persan, « rā’'ij ».

\section{INDEX}

Thèmes : 4.2.1. Safavides et Qâjârs 
AUTEURS

RUDI MATTHEE

Université de Delaware (États-Unis) 